\title{
The status and conservation of Jamaica's threatened and endemic forest avifauna and their habitats following Hurricane Gilbert
}

\author{
NIGEL VARTY
}

\section{Summary}

Despite serious and widespread hurricane damage to the natural forests of Jamaica ( $43 \%$ of trees either toppled or with crowns broken in the John Crow Mountains, for instance), the populations of the endemic Ring-tailed Pigeon Columba caribaea, Crested Quail-dove Geotrygon versicolor, Black-billed Parrot Amazona agilis, Yellow-billed Parrot $A$. collaria, Blue Mountain Vireo Vireo osburni and Jamaican Blackbird Nesopsar nigerrimus appear to have survived Hurricane Gilbert well. However, the expected reduction in food supplies, notably for the frugivores, caused by the severe damage to many trees, coupled with continuing and in some cases increasing human destruction and disturbance of the forests, puts the longer-term survival of these species in some doubt. The establishment of functioning protected areas encompassing the key forest regions for these birds; upgrading and more rigorous enforcement of the legislation governing conservation and management of wildlife and the natural forests; and the control and improvement of agricultural practices around forest areas, would greatly help to ensure the preservation of the forest avifauna and are recommended.

\section{Introduction}

On 12 September 1988 Hurricane Gilbert, the most powerful storm recorded in the Caribbean this century, hit Jamaica. Winds with gusts in excess of $220 \mathrm{~km} / \mathrm{hr}$ ripped across the island (ODP 1989) causing widespread damage to the island's mid-level and montane forests (Bellingham et al. in press).

Six of Jamaica's 25 endemic species of bird, the Ring-tailed Pigeon Columba caribaea, Crested Quail-dove Geotrygon versicolor, Black-billed Parrot Amazona agilis, Yellow-billed Parrot Amazona collaria, Blue Mountain Vireo Vireo osburni and Jamaican Blackbird Nesopsar nigerrimus are more or less restricted to these forests (Lack 1976, Downer and Sutton 1990). Prior to Hurricane Gilbert the populations of all six species were considered threatened or at some risk (Collar and Andrew 1988) and in decline (Haynes et al. 1989), mostly due to habitat destruction caused by government-sanctioned coffee and forestry-plantation development, clearance for crops and illegal cultivation, and timber and charcoal extraction (Johnson 1988).

Population declines and reduced breeding success of some Caribbean bird species are known to have occurred as a result of major storms in the region (Raffaele 1977, Jeggo and Taynton 1980, Smith and Temple 1982, Snyder et al. $1987)$ and in the immediate aftermath of the hurricane it was feared that the massive destruction wrought on the forests might have put the survival of all six 
species in jeopardy (Haynes-Sutton 1988). Consequently, in response to an official request from the government of Jamaica, an ICBP team carried out an assessment of the status of the endemic forest birds and their habitats between April and August 1989.

\section{Survey areas}

Bird and habitat surveys were conducted in the three largest and least disturbed expanses of natural forest remaining in Jamaica: the Blue Mountains, John Crow Mountains and Cockpit Country (Figure 1).

Blue Mountains (montane forest)

The Blue Mountains form the highest mountain range in Jamaica, rising to over $2,250 \mathrm{~m}$, and support the most extensive area of montane forest on the island. They comprise schists and shales and have steep slopes dissected by many short, fast-flowing streams. The higher areas are usually covered with mist for most of the day, and precipitation is high (yearly mean of $223 \mathrm{~cm}$ at Cinchona). The trees on the upper slopes and along the ridge are generally of small stature, up to $8 \mathrm{~m}$ tall, and epiphytes, particularly bromeliads, are conspicuous. Trees at lower altitudes reach greater heights, often over $20 \mathrm{~m}$ tall in sheltered gullies. Characteristic species of these forests include Cyrilla racemiflora, Podocarpus urbanii, Clethra occidentalis, Vaccinium meriodionale and Solanum punctulatum. Detailed accounts of the floristics and structure of these forests are given by Asprey and Robbins (1953), Grubb and Tanner (1976) and Tanner (1977, 1986). Surveys were concentrated in areas around Sir John's Peak (grid reference 13/ 878602), Morce's Gap (13/862599) and along the Vinegar Hill Trail (13/868610), and covered a range of forest types.

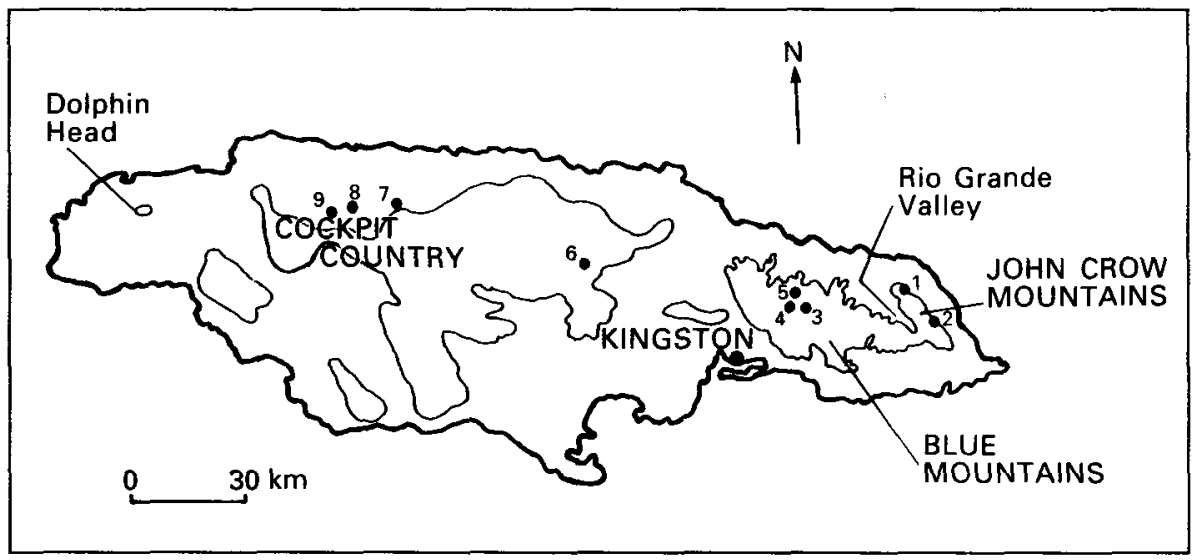

Figure 1. Map of Jamaica showing study areas and the $1,500 \mathrm{ft}(460 \mathrm{~m})$ contour line. 1, Hog House Hill; 2, Ecclesdown; 3, Sir John's Peak; 4, Morce's Gap; 5 , Vinegar Hill Trail; 6, Mount Diablo; 7, Barbecue Bottom; 8, Windsor; 9, Pantrepant. 
Cockpit Country (moist to wet limestone forest)

Cockpit Country encompasses a huge area of central Jamaica and comprises a plateau of hard limestone that has been eroded into a series of steep (often vertical-sided), rocky, conical hills, separated by depressions or "cockpits", each drained by a sinkhole at the bottom. Forest on the bottom of many cockpits, particularly those on the margins of Cockpit Country, has been cleared, but that on steep slopes and the tops of hills and in cockpits in the centre of the region is much less disturbed. The flora of these forests has been briefly described by Asprey and Robbins (1953) with additional notes by Proctor (1986). Surveys were carried out around the Windsor area $(52 \mathrm{C} / 326529)$, south of Pantrepant $(52 \mathrm{C} / 314526)$ and at Barbecue Bottom $(52 \mathrm{D} / 358533)$. All the forest areas covered were secondary.

John Crow Mountains (very wet limestone forest)

The John Crow Mountains are formed of a tilted limestone massif with a steep escarpment on the western side. The limestone has eroded to form a typical rugged "karst" terrain, not unlike that of Cockpit Country but less regular. This is one of the most inaccessible and least known upland areas of Jamaica. Due to the difficulty of the terrain much of the area is undisturbed and, as it lies directly in the path of the prevailing north-east trade winds, rainfall is very high, varying from an average of $378 \mathrm{~cm}$ per year at Ecclesdown on the east side of the range to $615 \mathrm{~cm}$ per year at Millbank in the Rio Grande Valley. The most abundant tree at lower altitudes is Calophyllum calaba and on the summit plateau Clusia havetioides. The vegetation of this region has been described by Asprey and Robbins (1953), Kelly (1986) and Kelly et al. (1988). Surveys were conducted west of Ecclesdown (14/1805650) and close to Hog House Hill (14/155603).

\section{Methods}

\section{Bird surveys}

The abundance and distribution of the six bird species were assessed using the following standard techniques:

Point counts (Variable Circular Plot method: Reynolds et al. 1980). These were conducted for eight minutes at $200 \mathrm{~m}$ intervals along forest trails.

Playback Each count was immediately followed by a five-minute broadcast of taped calls of Crested Quail-dove, Blue Mountain Vireo and Jamaican Blackbird, in order to gather additional information on the presence of these species at a site. Point counts and playbacks were conducted between $05 h_{45}$ and 11 h 45 .

Transects Counts of the six target species were also conducted along forest trails during both mornings and afternoons.

Parrot census A separate survey of Yellow-billed and Black-billed Parrots was 
conducted over a four-day period in July 1989 at Barbecue Bottom in Cockpit Country, using the method developed by Evans (1989) for censusing parrots in the mountainous forests on Dominica. A number of observers were positioned at vantage points overlooking this large cockpit along the Albert Town to Kinloss road. The number of parrots observed or heard in early morning (06h20-0gh3o) and late afternoon (17hoo-18h45) was recorded and their positions marked on a sketch map of the area in order to determine abundance and habitat use.

Notes were kept on the activity and height above ground of each individual bird during the surveys, where these could be determined.

Questionnaires Local foresters and hunters were questioned about the presence, abundance, movements, breeding and feeding activities of the six target species in the three forest areas.

\section{Assessment of forest structure and damage}

Both quantitative and qualitative assessments of the effect of the hurricane on the forest flora were conducted from ground and aerial surveys. Various habitat variables were measured within a $15 \mathrm{~m}$ radius of each bird count point, others were measured in a $5 \mathrm{~m}$ radius sub-plot, located $10 \mathrm{~m}$ away from the count point and perpendicular to the trail (Table 1).

Any vegetation along and bordering the path was ignored. Within the $5 \mathrm{~m}$ sub-plots only standing and fallen trees and shrubs with a diameter of breast height (DBH) greater or equal to $5 \mathrm{~cm}$ were measured. These were divided into two groups, those with a DBH between $5 \mathrm{~cm}$ and $15 \mathrm{~cm}$ and those with a DBH greater than $15 \mathrm{~cm}$. The degree of refoliation of the five trees closest to the centre of each sub-plot was also recorded.

\section{Impact of Hurricane Gilbert on Jamaica's mid-level and montane forests}

It was clear from the two flights made on 3 June and 3 August 1989 and during the ground surveys that all three forest areas had suffered severe and very extensive hurricane damage.

Table 1. Habitat parameters recorded at each bird count point used in the analyses

\begin{tabular}{ll}
\hline \multicolumn{1}{c}{ Habitat parameters } & \multicolumn{1}{c}{ Units/measures } \\
\hline $\begin{array}{l}\text { Within } 15 \text { m radius of sample point } \\
\text { Altitude }\end{array}$ & Metres \\
Aspect & Deviation from south in degrees \\
Slope & Degrees of main aspect \\
Canopy height & Mean canopy height in metres \\
& \\
Within $5 m$ radius sub-plot & \\
Unbroken standing trees & No. trees, DBH $5-15 \mathrm{~cm}$ and $>15 \mathrm{~cm}$ \\
Broken standing trees & No. trees, DBH $5-15 \mathrm{~cm}$ and $>15 \mathrm{~cm}$ \\
Fallen trees & No. trees, DBH $5-15 \mathrm{~cm}$ and $>15 \mathrm{~cm}$ \\
Refoliation & Refoliation of 5 trees closest to centre of plot \\
\hline
\end{tabular}


Table 2. Hurricane-caused damage to trees in Blue Mountains, John Crow Mountains and Cockpit Country $(n=$ number plots $)$

\begin{tabular}{lccc}
\hline & $\begin{array}{c}\text { Blue } \\
\text { Mountains } \\
(\mathrm{n}=64)\end{array}$ & $\begin{array}{c}\text { John Crow } \\
\text { Mountains } \\
(\mathrm{n}=70)\end{array}$ & $\begin{array}{c}\text { Cockpit } \\
\text { Country } \\
(\mathrm{n}=56)\end{array}$ \\
\hline $\begin{array}{l}\text { Tree density (no. stems with DBH }>5 \\
\left.\mathrm{~cm} \text { ha- }{ }^{-}\right)\end{array}$ & 4,400 & 3,200 & 1,700 \\
$\begin{array}{l}\text { Broken trees (\% stems ( } \pm \text { S.E.) with } \\
\text { trunks or crowns completely or } \\
\text { partly broken) }\end{array}$ & $23 \cdot 1(1 \cdot 4)$ & $14 \cdot 7(1 \cdot 1)$ & $17 \cdot 7(2 \cdot 1)$ \\
$\begin{array}{l}\text { Toppled trees (\% stems }( \pm \text { S.E.) } \\
\text { fallen) }\end{array}$ & $9 \cdot 2(1 \cdot 0)$ & $28 \cdot 1(1 \cdot 7)$ & $19 \cdot 9(2 \cdot 7)$ \\
\hline
\end{tabular}

Many trees were toppled or had their crowns or major limbs broken or snapped off and others were damaged or brought down by other windfall trees. The most severe damage in all three areas occurred along exposed ridges and the crests of hills, with trees in gullies suffering least. Landslides, created mostly by the heavy rains that accompanied the hurricane, had totally destroyed the forest in places, particularly in the Blue Mountains where large numbers of recently formed landslides, some estimated to be several hundred metres long, were observed in the Swift, Stony and Back Rio Grande valleys. The majority of trees and shrubs were reported to have been largely or totally defoliated by the hurricane and most plants in flower or fruit lost their blooms or crop, which local foresters claimed had reduced seed and fruit production in the following season (C. Deacon and G. Hall verbally). In the most severely damaged areas where canopy cover was still poor there was a prolific growth of herbaceous vegetation, lianas and creepers covering the ground and remains of trees.

The proportion of trees and shrubs with tops broken or snapped was greatest in the Blue Mountains, but the number of trees toppled was higher in the John Crow Mountains (Table 2). Multivariate analyses revealed no significant relationships between damage and aspect, slope or altitude in any of the three forest areas. Aerial photographs taken on 3 June show an estimated $90 \%$ of all trees on the north-east-facing slope of Crayfish Hill (4 km south-east of Millbank) had been blown down and the remaining trees badly damaged. As expected, the larger trees suffered the greatest damage (Table 3).

Table 3. Results of $t$-tests comparing mean damage to small trees and mean damage to large trees (data transformed)

\begin{tabular}{|c|c|c|c|}
\hline & $\begin{array}{c}\text { Blue } \\
\text { Mountains } \\
(n=64)\end{array}$ & $\begin{array}{c}\text { John Crow } \\
\text { Mountains } \\
(\mathbf{n}=70)\end{array}$ & $\begin{array}{l}\text { Cockpit } \\
\text { Country } \\
(n=56)\end{array}$ \\
\hline Mean damage to small trees & $32 \cdot 1 \%$ & $35 \cdot 1 \%$ & $22.5 \%$ \\
\hline Mean damage to large trees & $32 \cdot 1 \%$ & $58 \cdot 6 \%$ & $44 \cdot 4 \%$ \\
\hline$t$-value & 0.839 & 6.302 & $3 \cdot 259$ \\
\hline Probability level & $p>0.2$ & $p \leqslant 0.001$ & $0.001<p \leqslant 0.01$ \\
\hline
\end{tabular}


Although very few areas of forest were untouched by the hurricane, damage varied tremendously, with $70-100 \%$ of the larger trees down in some plots (Figure 2). This suggests that the local topography and perhaps forest type had a major influence on the severity of damage. The hurricane winds themselves may also have varied widely. The patchiness of the damage was particularly noticeable in the John Crow Mountains, where it was possible to walk through areas of almost undamaged forest and areas with more than half the trees down in the distance between bird-count points $(200 \mathrm{~m})$.

Although the forests in some areas appeared almost lifeless $(80-90 \%$ of the John Crow escarpment east of the town of Millbank was still grey-brown with little or no apparent regrowth in April, seven months after the hurricane), the majority of trees and shrubs in the three areas already showed some signs of refoliation by the time the surveys began. Overall, $10 \%$ of trees and shrubs surveyed in the Blue Mountains, $2 \%$ in Cockpit Country and $7 \%$ in the John Crow Mountains were still completely bare (either dead or alive but yet to
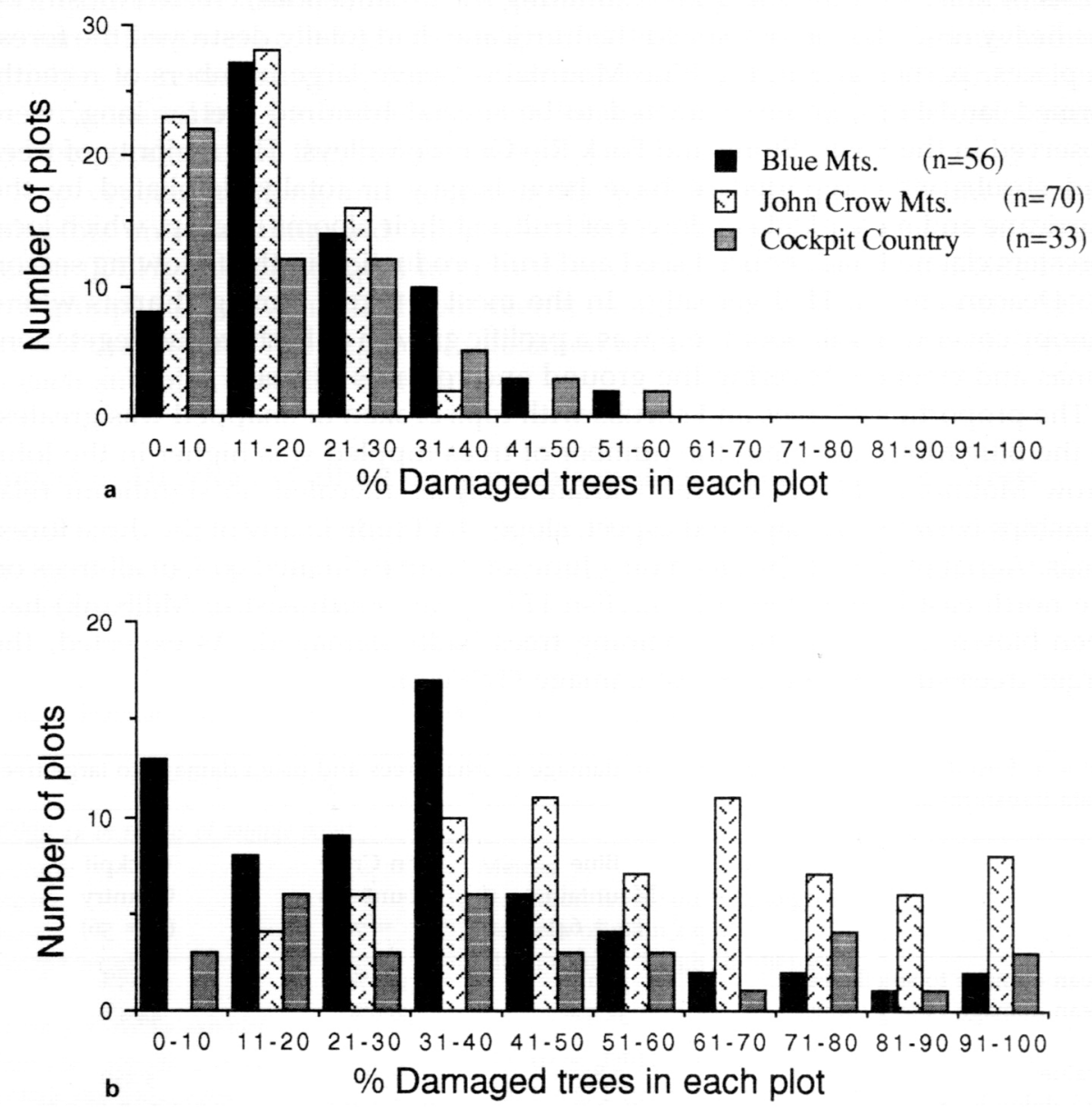

Figure 2. Hurricane damage to trees; $a$, small trees $(5 \mathrm{~cm}<\mathrm{DBH}<15 \mathrm{~cm})$; b, large trees (DBH $>15 \mathrm{~cm})$. 
produce leaves). However, bare trees were not necessarily lifeless; some trees which had been totally stripped by the hurricane were only beginning to show signs of life as late as the end of the final field surveys in July (10 months after the hurricane) and consequently only clearly rotting trees could be regarded as dead.

\section{Impact of Hurricane Gilbert on the status and breeding of the endemic forest avifauna}

Other than Lack (1976) there is very little quantitative information on the abundance of Jamaica's endemic forest avifauna prior to Hurricane Gilbert, which makes an assessment of changes in the status of these species following the hurricane limited.

Ring-tailed Pigeon This species was considered threatened prior to the hurricane (Collar and Andrew 1988). Although often recorded during point counts (Table 4), this species was probably much rarer than it appeared. Since calling birds

Table 4. Number of records and frequency of occurrence of Ring-tailed Pigeon, Crested Quaildove, Yellow-billed Parrot, Black-billed Parrot, Blue Mountain Vireo and Jamaican Blackbird

\begin{tabular}{|c|c|c|c|}
\hline & $\begin{array}{c}\text { Blue } \\
\text { Mountains } \\
(\mathrm{n}=7 \mathrm{o})\end{array}$ & $\begin{array}{c}\text { John Crow } \\
\text { Mountains } \\
(\mathrm{n}=7 \mathrm{o})\end{array}$ & $\begin{array}{l}\text { Cockpit } \\
\text { Country } \\
(n=56)\end{array}$ \\
\hline \multicolumn{4}{|l|}{ Ring-tailed Pigeon } \\
\hline No. birds recorded during counts & 57 & 41 & 39 \\
\hline$\%$ points birds recorded during counts & $4^{1}$ & 41 & 37 \\
\hline \multicolumn{4}{|l|}{ Crested Quail-dove } \\
\hline No. birds recorded during counts & 5 & 12 & 6 \\
\hline$\%$ points birds recorded during counts & 4 & 14 & 7 \\
\hline $\begin{array}{l}\text { Additional birds recorded during } \\
\text { playback (total no. birds recorded) }\end{array}$ & o (5) & $3(15)$ & $5(11)$ \\
\hline Total \% points birds recorded & 4 & 19 & 14 \\
\hline \multicolumn{4}{|l|}{ Yellow-billed and Black-billed Parrots } \\
\hline No. birds recorded during counts & & 99 & 98 \\
\hline Total \% points birds recorded & & 63 & 79 \\
\hline \multicolumn{4}{|l|}{ Blue Mountain Vireo } \\
\hline No. birds recorded during counts & 29 & 22 & 29 \\
\hline$\%$ points birds recorded & 34 & 23 & 29 \\
\hline $\begin{array}{l}\text { Additional birds recorded during } \\
\text { playback (total no. birds recorded) }\end{array}$ & $24(53)$ & $51(73)$ & $24(53)$ \\
\hline Total \% points birds recorded & 53 & 69 & 54 \\
\hline \multicolumn{4}{|l|}{ Jamaican Blackbird } \\
\hline No. birds recorded during counts & 51 & 19 & o \\
\hline$\%$ points birds recorded & 39 & 21 & o \\
\hline $\begin{array}{l}\text { Additional birds recorded during } \\
\text { playback (total no. birds recorded) }\end{array}$ & $6(57)$ & $8(27)$ & $1(1)$ \\
\hline Total \% points birds recorded & 44 & 29 & 2 \\
\hline
\end{tabular}


could be heard more than $300 \mathrm{~m}$ away there may have been some over-recording of this species. Other factors, such as the tendency for birds to occur in groups, their mobile nature (moving between areas of fruiting trees) and their preference for the canopy, make this species difficult to census accurately. Local people around all three forest areas claimed to have seen far fewer birds in $1989 \mathrm{com}-$ pared with the same period in 1988 prior to the hurricane. However, comparison with data from Lack (1976) and Momot (1985) suggests little decline (Table 5).

Birds were seen and heard calling in the Blue Mountains from mid-April up until the end of the field surveys in this area in mid-June. In Cockpit Country Ring-tailed Pigeons were recorded during visits in mid-April and late July and in the John Crow Mountains from mid-May until the last visit in early July. This supports assertions by hunters that Ring-tailed Pigeons move to the forest areas to breed in mid-late April, descending to lower areas outside the breeding season, apparently from August (C. Rousseau verbally), and suggests that Hurricane Gilbert had not prevented these seasonal movements. Although Ringtailed Pigeons were frequently heard calling in all three forest areas, and many birds were seen in pairs, no juveniles were observed.

Crested Quail-dove Rarely recorded during point counts or playbacks (Table 4), this species was most often disturbed on or near forest trails during transect walks. Since this species is predominantly a ground-dweller (Lack 1976, Downer and Sutton 1990) and is generally silent, many were probably overlooked. Local foresters and hunters around the John Crow Mountains and Cockpit Country claimed that the Crested Quail-dove populations had been little affected by the hurricane, although the numbers during 1989 were somewhat lower than those

Table 5. Numbers of birds per 10-hour period recorded during present study and by Lack (1976) in summer

\begin{tabular}{|c|c|c|c|c|c|c|c|}
\hline \multirow[t]{3}{*}{ Species } & \multicolumn{3}{|c|}{ Present study } & \multicolumn{4}{|c|}{ Lack (1976) } \\
\hline & \multicolumn{2}{|c|}{ Montane } & \multirow{2}{*}{$\begin{array}{l}\text { Mid-level } \\
\text { CC }\end{array}$} & \multirow[b]{2}{*}{$\mathrm{HF}$} & \multicolumn{2}{|c|}{ Montane } & \multirow{2}{*}{$\begin{array}{l}\text { Mid-level } \\
\text { WL }\end{array}$} \\
\hline & $\mathrm{BM}$ & $\mathrm{JC}$ & & & MG & VWL & \\
\hline Ring-tailed Pigeon & $13 \cdot 3$ & $17 \cdot 3$ & $31 \cdot 4$ & 17 & 40 & 9 & 63 \\
\hline Crested Quail-dove & $7 \cdot 9$ & $9 \cdot 0$ & $7 \cdot 5$ & 18 & 28 & 20 & 14 \\
\hline $\begin{array}{l}\text { Yellow-billed and } \\
\text { Black-billed Parrots }\end{array}$ & 0 & $59 \cdot 5$ & $85 \cdot 0$ & o & 0 & 55 & 80 \\
\hline Blue Mountain Vireo & $11 \cdot 1$ & $26 \cdot 6$ & $21 \cdot 1$ & 6 & o & 18 & 16 \\
\hline \multirow[t]{3}{*}{ Jamaican Blackbird } & $22 \cdot 7$ & $12 \cdot 6$ & o & 5 & 12 & $<0.5$ & 2 \\
\hline & \multicolumn{7}{|c|}{ Number of birds per 10-hour period from Momot (1985) } \\
\hline & $\begin{array}{l}19 \\
M\end{array}$ & & $\begin{array}{l}1979 \\
\text { Apr }\end{array}$ & $\begin{array}{c}1979 \\
\text { Oct }\end{array}$ & & $\begin{array}{l}80 \\
\text { lay }\end{array}$ & $\begin{array}{l}1981 \\
\text { May }\end{array}$ \\
\hline Ring-tailed Pigeon & 30 & & $19 \cdot 2$ & 1.6 & & 2 & $9 \cdot 4$ \\
\hline Crested Quail-dove & 0 & & o & $1 \cdot 0$ & & $\cdot 2$ & $0 \cdot 4$ \\
\hline
\end{tabular}

BM, Blue Mountains; JC, John Crow Mountains; CC, Cockpit Country; HF, Hardwar Forest; MG, Morce's Gap trail; WL, wet limestone; VWL, very wet limestone. 
of Lack (1976) (Table 5). The counts of Crested Quail-doves derived by Momot (1985) varied very widely (Table 5) and are of little comparative use.

Juvenile Crested Quail-doves were observed in the Blue Mountains in April, indicating that the birds had successfully bred within 6-7 months of the hurricane.

Yellow-billed and Black-billed Parrots Black-billed Parrots were recorded in Cockpit Country and the John Crow Mountains, although only in the Hog House Hill area of the latter, not in the south of the massif around Ecclesdown or on the escarpment near Millbank. Scott (1891-1893) reported that this species was common at the northern end of the mountains, but Lack (1976) did not record it and stated that "no modern ornithologist has seen it in the John Crow Mountains". However, Knox and Knox (1974) and Siphron (1976) reported this species from both the northern and southern ends of the range. It may be that major storms, such as Hurricane Gilbert, blow birds to the John Crow Mountains from Cockpit Country or Mount Diablo and that these stragglers survive for a while.

Since it was frequently impossible to separate the calls of these two species and most records were of calling birds, data on parrots collected during point counts and transects have been grouped (Table 4). The numbers of parrots observed during the transects (Table 5) were similar to those of Lack (1976). Overall the relative abundance (number of separate records) of Yellow-billed and Black-billed Parrots recorded at Barbecue Bottom in the mornings of 15-17 July 1989 was slightly higher than that recorded by Cook (1984) on the morning of 7 August 1983 (Table 6). However, the relative abundance of the two species (based on visual records) differed markedly between the two studies, with Yellow-billed Parrots apparently commoner and Black-billed Parrots rarer than reported by Cook (1984).

Yellow-billed Parrots were observed feeding well-developed young in Cockpit Country in late July, indicating at least some successful breeding within 10 months of Hurricane Gilbert. However, there was no evidence of successful breeding of Black-billed Parrots.

Blue Mountain Vireo Since many more Blue Mountain Vireos were attracted by playback of their calls (Table 4), this species was clearly under-recorded. Cockpit Country supported the highest density of birds, the Blue Mountains the lowest (Table 7). The numbers recorded during transects were a little higher than those

Table 6. Relative abundance (mean number [ \pm se] of independent observations, between o6h3o and oghoo of Yellow-billed and Black-billed Parrots at Barbecue Bottom, Cockpit Country, during present study and by Cook (1984)

\begin{tabular}{lcc}
\hline & $\begin{array}{c}(\text { Cook 1984) } \\
(\mathrm{n}=1)\end{array}$ & $\begin{array}{c}(\text { Present study }) \\
(\mathrm{n}=3)\end{array}$ \\
\hline Yellow-billed Parrot & 8 & $74 \pm 1$ \\
Black-billed Parrot & 84 & $34 \pm 10$ \\
Unidentified parrot & 108 & $142 \pm 9$ \\
Total number of parrots & 200 & $250 \pm 34$ \\
\hline
\end{tabular}


Table 7. Density estimates (number per hectare) for Blue Mountain Vireo and Jamaican Blackbird

\begin{tabular}{lccc}
\hline & $\begin{array}{c}\text { Blue } \\
\text { Mountains }\end{array}$ & $\begin{array}{c}\text { John Crow } \\
\text { Mountains }\end{array}$ & $\begin{array}{c}\text { Cockpit } \\
\text { Country }\end{array}$ \\
\hline Blue Mountain Vireo & 29 & 22 & 29 \\
Number of records & 0.20 & 0.35 & 0.61 \\
Variable circular plot estimates & 0.22 & 0.43 & 0.78 \\
Probability model estimates* & & & \\
Jamaican Blackbird & 51 & 19 & \\
Number of records & 0.44 & 0.20 & \\
Variable circular plot estimate & 0.56 & 0.23 & \\
Probability model estimate* & & & \\
\hline
\end{tabular}

${ }^{*} \mathrm{D}=\log _{\mathrm{e}}(\mathrm{n} / \mathrm{n} \mathrm{n})\left(\mathrm{n} / \mathrm{m} \quad \mathrm{r}^{2}\right)$, where $\mathrm{D}=$ density, $\mathrm{n}=$ total number of birds detected, $\mathrm{n} 2=$ number outside pre-selected radius ( $r$ ) and $m=$ number of points.

reported by Lack (1976), again suggesting little dramatic change in numbers due to the hurricane. Mitchell (1989) gave the density of Blue Mountain Vireo in an area of forest between Morce's Gap and Cinchona (grid reference 13/863578) as $0.47 \mathrm{birds} / \mathrm{ha}$, over twice that of the present study.

Groups of three or four birds, including juveniles, frequently approached the observer during playback, suggesting a family group. One bird was observed with nesting material in its beak in late June in the John Crow Mountains.

Jamaican Blackbird Only two birds were recorded in Cockpit Country, both at Pantrepant in mid-April and late July, and both in cockpits which had suffered little disturbance by man. Density was greatest in the Blue Mountains (Table 7), where birds appeared to be commonest in the higher areas that had suffered the least disturbance by man (upper catchments of the Mabess, Spanish, Swift, Back Rio Grande and Stony Rivers). Wiley and Cruz (1980) give the mean maximum diameter of the Jamaican Blackbird range as $281 \mathrm{~m}$ which, assuming a circular distribution to the range, would give a density of $0.16 \mathrm{birds} / \mathrm{ha}$, lower than the present study. The numbers of birds recorded during transects was greater than those reported by Lack (1976) (Table 5), which similarly suggests an increase in numbers following Hurricane Gilbert. This is likely to be artificial, probably due to increased detectability in hurricane-damaged forest. Two nests with young were discovered in the Blue Mountains (May) and John Crow Mo'untains (June), and small family parties (3-4 birds) were recorded in both areas.

\section{Changes in feeding behaviour of forest birds following Hurricane Gilbert}

Those birds which survived the immediate force of the hurricane had to contend with a reduction in their food supplies, created by the massive defoliation of forest trees and the loss of flowers and fruit. It is likely that many birds died of starvation but some moved out of the forests. Local farmers in the Pantrepant and Windsor areas of Cockpit Country claimed that parrots descended to agricultural areas to feed after the hurricane, remaining around their fields for 
Table 8. Comparison of Jamaican Blackbird feeding sources in forests following Hurricane Gilbert (present study) with those in undamaged forests (Lack 1976, Wiley and Cruz 1980)

\begin{tabular}{lccc}
\hline & Present study & Lack (1976) & Wiley and Cruz (1980) \\
\hline Number observations & 40 & 82 & 178 \\
Percentage of observed foraging sites & & & \\
Bromeliads & 15 & 46 & 77 \\
Tree ferns & 7 & 15 & 8 \\
Mosses & 23 & 18 & 14 \\
Cracks in and under bark & 14 & 6 & \\
Lichens & 12 & 5 & $<1$ \\
Dead leaves and branches & 15 & 4 & \\
Living trees and branches & 2 & 1 & \\
Ground & 10 & 1 & \\
Wild flowers & 0 & 2 & \\
\hline
\end{tabular}

several weeks. Wunderle et al. (ms) also found evidence that some of the montane species may have moved into less damaged lowland areas. Other species appeared to expand their diet following the storm. Previous studies have shown that Jamaican Blackbirds find most of their invertebrate food amongst the bracts of bromeliads (Lack 1976, Wiley and Cruz 1980). Many of these plants and the larger trees on which they grew were blown down by the hurricane, so it was expected that food would be scarce for the birds. However, Jamaican Blackbirds were observed foraging successfully among many other sources of food (Table 8) and were able to breed.

\section{Increased threats to the forest avifauna since the hurricane}

Before Hurricane Gilbert Jamaica's forest avifauna was primarily threatened by various forms of habitat destruction. These were principally the replacement of large areas of natural forests by pine or coffee plantations under the direction of the Forest Industries Development Corporation (FIDCO) and the Coffee Industry Development Corporation (CIDCO), clearance of forest for livestock farming, the cultivation of basic staple and cash crops and marijuana Cannabis sativa, and timber and charcoal extraction (Haynes et al. 1989). Hunting also appears to have had a serious impact on some species (Haynes et al. 1989). Hurricane Gilbert has clearly intensified the pressure on the birds from some of these activities.

The hurricane caused serious erosion to exposed areas, especially on steep slopes in the parishes of St Andrew, St Thomas, St Mary, Portland, sections of St Catherine, Hanover, St James, Clarendon and Manchester (NRCD 1988). Many farmers lost most or all of their cultivated areas which increased demand for new land and therefore deforestation. Site visits and the aerial surveys revealed evidence of extensive recent clearance in the three main forest areas and on Dolphin Head in the far west of Jamaica. Clearance in the Blue Mountains was increasingly spreading to higher, steeper areas, and slopes only a few thousand 
feet below Blue Mountain Peak recorded burning on several occasions in May and June 1989.

Unfortunately, suitable land management practices on steep slopes, such as proper terracing, are lacking in many places. Consequently, crop production from recently cleared areas is likely to be short-lived, leading to further pressure on the forests. The situation has been exacerbated by the misuse of some of the many chainsaws brought to Jamaica to facilitate the clear-up and which have been turned instead to extracting timber and clearing forest.

Hurricane Gilbert resulted in the blockage of most forest trails, restricting access to bird hunters, and this probably reduced the numbers of Ring-tailed Pigeon and Crested Quail-dove shot and Yellow-billed and Black-billed Parrot collected in 1989. Inevitably, the trails are gradually being cleared, mostly by local people to gain access to agricultural plots or for timber or fuelwood extraction.

\section{Conservation of the forest avifauna}

In light of the hurricane damage to Jamaica's forests and the continuing manmade threats to these areas various measures must be undertaken to ensure the preservation of the forest avifauna. Combating deforestation must be seen as the principal target for the conservation of Jamaica's forest avifauna: for the period 1980-1986 the annual rate of deforestation in Jamaica was $3.3 \%$, a rate comparable with that of Haiti (Eyre 1987).

\section{Habitat and species protection}

Establishment of protected areas All six of the endemic forest birds occur in the John Crow Mountains. From the surveys and brief reconnaissance visits it is also clear that the northern slopes of the Blue Mountains support good populations of forest birds, particularly Jamaican Blackbirds. Regions encompassing all or part of these areas, where human activities (except perhaps research) are forbidden, should be created within the new Blue and John Crow Mountain National Park. The forests of Cockpit Country still appear to support the greatest concentration of both the Yellow-billed and Black-billed Parrots in Jamaica. This region should also be declared a national park. Since a number of the forest bird species, such as Ring-tailed Pigeon, show seasonal altitudinal movements it is recommended that "corridors" of suitable habitat linking forest and lowland areas be maintained contiguous to these protected areas. In addition, it is suggested that a buffer zone, where habitat clearance is prohibited and other human activities are regulated, be established around the protected areas.

Cessation of forest clearance The majority of the land covered by natural forest in the Blue and John Crow Mountains and Cockpit Country is classified as forest reserve, wherein a wide range of activities, including felling, are prohibited or restricted (Forest Act, 1937). Unfortunately, forest reserves incorporating natural forest are frequently poorly policed and managed by the Forestry and Soil Conservation Department (FSCD) and need to be improved. Higher penalties 
should be incurred for illegal clearance and the ownership and use of chainsaws needs to be more carefully regulated. It is recommended that there is a moratorium on further clearance of natural forests by FIDCO and CIDCO within the Blue and John Crow Mountains and Cockpit Country.

Improvement of agricultural practices Pressure from farmers for forest land could be reduced if more soil conservation programmes were implemented in areas around the natural forests. Investigation of methods to improve crop production on marginal lands in these regions would also benefit forest conservation.

Stricter controls over hunting Ring-tailed Pigeons, Crested Quail-doves, Yellowbilled and Black-billed Parrots are protected by the Wildlife Protection Act of 1945. However, illegal shooting of Ring-tailed Pigeon and Crested Quail-dove still occurs in the forest areas. The seasonal concentrations of Ring-tailed Pigeons at known localities make this species especially vulnerable to illegal shooting. In addition, Yellow-billed and Black-billed Parrots continue to be captured in Cockpit Country and along the north coast (M. Schwartz verbally, pers. obs.) for sale as pets within Jamaica, sold to tourists or exported overseas (mostly to the United States of America). It is recommended that hunting of all wild birds (and all other animals) be prohibited within any protected areas or natural forest reserves.

\section{Improvement and implementation of wildlife legislation}

The conservation of Jamaica's forests and their wildlife is included in the remits of several government departments, notably the Natural Resources Conservation Department (NRCD) and the FSCD. However, shortage of adequately trained staff and a lack of finance from central government combine to restrict severely what these bodies can achieve. NRCD is expected to become a statutory authority within the next few years with a strengthened legislation and an increased budget. It is hoped that this will improve the Jamaican government's ability to carry out effective conservation action, such as the enforcement of the Wildlife Protection Act. The government of Jamaica is not a signatory to CITES (T. P. Inskipp verbally) and should be encouraged to become a member, since this would help to combat the illicit trade in Yellow-billed and Black-billed Parrots.

\section{Development of environmental education programmes}

A major hindrance to wildlife conservation in Jamaica is the public's general lack of appreciation of the value (ecological, aesthetic, practical and economic) of the island's natural areas. Educational programmes aimed at correcting this ignorance, targeted on Jamaica's forests, their flora and fauna and illustrating the importance of forests for protecting soils and water supplies, deserve high priority. These programmes should be especially aimed at communities around forest areas. 


\section{Additional research requirements}

The ecology of much of Jamaica's endemic avifauna remains poorly known, especially the forest species. Basic information needed to make management decisions for these species is still generally lacking and needs to be obtained.

\section{Discussion}

Many species of bird in suburban and agricultural areas in Jamaica, such as Redbilled Streamertail Trochilus polytmus, were reported to be rare for several months after the storm (Gosse Bird Club 1988, 1989) and some, such as the Common Potoo Nyctibius griseus, were still difficult to find over a year later (A. Haynes-Sutton and R. Sutton verbally). Much of the evidence for the declines in bird populations following Hurricane Gilbert is anecdotal. However, Wunderle et al. (ms) were able to re-survey to habitats four months after the hurricane that had previously been sampled in December 1987. They found the mean number of individual birds (all species recorded) declined in three montane habitats (cloud-forest, pine and coffee plantation), increased at two lowland sites (wet limestone forest and mangroves) but stayed the same in the remaining five lowland habitats (coffee plantation, second growth forest, pasture, dry limestone "ruinate" forest and dry limestone forest). Their results indicate that there was no general pattern of decline across Jamaica.

Although there is a lack of quantitative data on the populations of the endemic forest birds prior to Hurricane Gilbert, the findings of this study suggest that the populations of the Ring-tailed Pigeon, Crested Quail-dove, Yellow-billed Parrot, Black-billed Parrot, Blue Mountain Vireo and Jamaican Blackbird survived the immediate and short-term effects of the hurricane well, and that their situation had not become critical. Their numbers were not dramatically different from those of previous studies and, in addition, there was evidence of successful breeding for Crested Quail-dove, Yellow-billed Parrot, Blue Mountain Vireo and Jamaican Blackbird within 1o months of the storm. However, it should be borne in mind that the apparent abundance of these species may be partly a reflection of increased movements in search of scarcer food (hence detectability) rather than their true numbers.

However, marked declines of Jamaica's forest bird populations may occur in the longer term. Although it was apparent from the vegetation surveys that certain sections of the forests were regenerating quickly, the destruction of some areas was so complete that it will probably take many years (time for seedlings to grow to mature adult trees) for the whole of each forest area to become reestablished. Consequently food supplies for some species, notably the frugivores (Ring-tailed Pigeon, Crested Quail-dove, Yellow-billed Parrot and Blackbilled Parrot), are likely to be reduced for perhaps several years, leading to declines of their populations. Wunderle et al. (ms) found that population declines in montane habitats were related to diet, with the populations of nectarivorous and frugivorous/granivorous species suffering a more marked decline than those of insectivorous species, which they suggest indicates that the greatest stress on Jamaica's montane bird populations occurred after its passage rather than during its impact. 
Further reductions due to destruction of nest sites by the storm may decrease breeding. Both Yellow-billed and Black-billed Parrots, for instance, nest in large hollow trees. Hurricane Gilbert severely damaged or blew over $59 \%$ and $44 \%$ of the larger trees in the John Crow Mountains and Cockpit Country respectively, and consequently many of the parrots' former nesting trees were undoubtedly lost.

Hurricanes are not infrequent visitors to Jamaica ( 16 have directly hit the island since 1871 ) and it is likely that Jamaica's natural forests are always in some state of recovery from these storms and consequently may rarely, if ever, reach a climax community. The forest avifauna is probably adapted to this dynamic system and, if the forests are left undisturbed, would in all likelihood recover to previous population levels. The concern is that the activities of man affecting the forests, some of which appear to have intensified since the hurricane, may reduce the bird populations to such a level that they cannot recover from the impact of future hurricanes as severe as Gilbert. In view of these threats it is imperative that adequate protection is given to these forest areas as soon as possible.

\section{Acknowledgements}

The International Council for Bird Preservation wishes to thank the Directorate-General for Development (DG8), Commission of the European Communities, and the S. Dillon Ripley Conservation Fund for their financial support. ICBP also wishes to express its gratitude to all those people who offered advice on or provided help with the field surveys in Jamaica, especially Dr Marcel Anderson and all his staff at NRCD, Jeannie Harvey, Mimi Schaffer, Meg and Tristan Fjelstad (United States Peace Corps), Jill Roberts (British High Commission, Kingston), Rhema Kerr (Hope Zoological Gardens), Dr Sue Iremonger (University of the West Indies, Kingston), Peter Bellingham and Jim Dalling (University of Cambridge), Charles Rousseau, Cecil Deacon, George Hall, Mike Schwartz and Tim Inskipp.

\section{References}

Asprey, G. F. and Robbins, R. G. (1953) The vegetation of Jamaica. Ecol. Monogr. 23: 359-412.

Bellingham, P. J., Kapos, V., Varty, N., Healey, J. R., Tanner, E. V. J., Kelly, D. L., Dalling, J. W., Burns, L. S., Lee, D. and Sidrak, G. (in press) Catastrophic disturbance need not cause high mortality: the effects of a major hurricane on forests in Jamaica. $J$. Trop. Ecol.

Collar, N. J. and Andrew, P. (1988) Birds to watch: the ICBP world checklist of threatened birds. Cambridge, U.K.: International Council for Bird Preservation (Techn. Publ. 8).

Cook, J. (1984) Jamaican Amazona Parrot expedition. Unpublished report to ICBP.

Downer, A. C. D. and Sutton, R. L. S. (1990) Birds of Jamaica: a photographic field guide. Cambridge: Cambridge University Press.

Evans, P. G. H. (1988) The conservation status of the Imperial and Red-necked Parrots on the island of Dominica, West Indies. Cambridge, U.K.: International Council for Bird Preservation (Study Report 27).

Eyre, L. A. (1987) Jamaica: test case for tropical deforestation? Ambio 16: 338-343.

Gosse Bird Club (1988) Observations on the effects of Hurricane Gilbert on bird life in Jamaica. Gosse Bird Club Broadsheet 51: 2-7. 
Gosse Bird Club (1989) Post-hurricane observations. Gosse Bird Club Broadsheet 52: 8-9.

Grubb, P. J. and Tanner, E. V. J. (1976) The montane forests and soils of Jamaica: a reassessment. J. Arnold Arboretum 57: 313-368.

Haynes, A. M., Sutton, R. L. S. and Harvey, J. D. (1989) Conservation trends and the threats to endemic birds in Jamaica. Biogeography of the West Indies 1989: 827-838.

Haynes-Sutton, A. M. (1988) Hurricane Gilbert strikes Jamaica's unique birdlife. World Birdwatch 10: 1,11.

Jeggo, D. F. and Taynton, K. M. (1980) The effects of Hurricane Allen on the status of the St. Lucia Parrot Amazona versicolor. Dodo 17: 11-18.

Johnson, T. H. (1988) Biodiversity and conservation in the Caribbean: profiles of selected islands. Cambridge, U.K.: International Council for Bird Preservation (Monogr. 1).

Kelly, D. L. (1986) Native forests on wet limestone in north-eastern Jamaica. Pp. 31-42 in D. A. Thompson, P. K. Bretting and M. Humphreys, eds. Forests of Jamaica. Kingston, Jamaica: The Jamaican Society of Scientists and Technologists.

Kelly, D. L., Tanner, E. V. J., Kapos, V., Dickinson, T. A., Goodfriend, G. A. and Fairburn, P. (1988) Jamaican limestone forests: floristics, structure and environment of three examples along a rainfall gradient. I. Trop. Ecol. 4: 121-156.

Knox, K. and Knox, S. D. (1974) Black-billed Parrot. Gosse Bird Club Broadsheet 23: 23.

Lack, D. (1976) Island biology. Oxford: Blackwell.

Mitchell, T. C. (1989) A study of the influence of an introduced plant species Pittosporum undulatum on faunal and floral diversity, structure and composition in the Blue Mountains of Jamaica. Bachelor of Science degree thesis submitted to the University of Cambridge, U.K.

Momot, J. J. (1985) NRCD Columbid programs; summary report. Unpublished report to Natural Resources Conservation Department, Kingston, Jamaica.

NRCD (1988) Hurricane Gilbert: destruction of watersheds. Report prepared by the Natural Resources Conservation Division, Ministry of Production, Planning and Development, Government of Jamaica.

ODP (1988) Hurricane Gilbert and its effects on Jamaica. Report prepared by the Office of Disaster Preparedness, Government of Jamaica.

Proctor, G. R. (1986) Cockpit Country and its vegetation. Pp. 43-47 in D. A. Thompson, P. K. Bretting and M. Humphreys, eds. Forests of Jamaica. Kingston, Jamaica: The Jamaican Society of Scientists and Technologists.

Raffaele, H. A. (1977) Comments on the extinction of Loxigilla portoricensis grandis in St. Kitts, Lesser Antilles. Condor 79: 389-39o.

Reynolds, R. T., Scott, J. M. and Nussbaum, R. A. (1980) A variable circular-plot method for estimating bird numbers. Condor 82: 309-313.

Scott, W. E. D. (1891-1893) Observations on the birds of Jamaica, West Indies. Auk 8: 249256, 353-365; 9: 9-15, 120-129, 273-777, 369-375; 10: 177-181, 339-342.

Siphron, J. (1976) Corn Puss Gap Birdlife. Gosse Bird Club Broadsheet 27: 4-5.

Smith, T. B. and Temple, S. A. (1982) Grenada Hook-billed Kites: recent status and life history notes. Condor 84: 131 .

Snyder, N. F. R., Wiley, J. W. and Kepler, C. B. (1987) The parrots of Luquillo: natural history and conservation of the Puerto Rican Parrot. Los Angeles: Western Foundation of Vertebrate Zoology.

Tanner, E. V. J. (1977) Four montane rain forests of Jamaica: a quantitative characterization of the floristics, the soils and the foliar mineral levels, and a discussion of the interrelations. J. Ecol. 65: 883-918.

Tanner, E. V. J. (1986) Forests of the Blue Mountains and the Port Royal Mountains of Jamaica. Pp. 15-30 in D. A. Thompson, P. K. Bretting and M. Humphreys, eds. Forests of Jamaica. Kingston, Jamaica: The Jamaican Society of Scientists and Technologists.

Wiley, R. H. and Cruz, A. (1980) The Jamaican Blackbird: a 'natural experiment' for hypotheses in socioecology. Evol. Biol. 13: 261-293. 
Wunderle, J. M., Lodge, D. J. and Waide, R. B. (ms) Short-term effects of Hurricane Gilbert on terrestrial bird populations on Jamaica.

\section{NIGEL VARTY}

International Council for Bird Preservation, 32 Cambridge Road, Girton, Cambridge $\mathrm{CB}_{3}$ oPJ, U.K. 